Saudi Journal of Medical and Pharmaceutical Sciences

Abbreviated Key Title: Saudi J Med Pharm Sci

ISSN 2413-4929 (Print) |ISSN 2413-4910 (Online)

Scholars Middle East Publishers, Dubai, United Arab Emirates

Journal homepage: https://saudijournals.com

Original Research Article

\title{
Mucoprotective Activity of Shark Liver Oil on Ethanol Induced Gastric Ulcer in Rats
}

\author{
S. A. Auti ${ }^{1 *}$, V. H. Kulkarni ${ }^{1}$, S. T. Shukla ${ }^{1}$, N.A. Magadum ${ }^{2}$ \\ ${ }^{1}$ SET'S College of Pharmacy, S.R. Nagar, Dharwad-580002, Karnataka, India \\ ${ }^{2}$ Dr. N. A. Magadum Ayurvedic Medical College, Hospital \& Research Centre, ANKALI-591213, District Belgaum, Karnataka, India
}

DOI: $\underline{10.36348 / \text { sjmps.2021.v07i01.005 }}$

| Received: 29.09.2020 | Accepted: 13.10.2020 | Published: 14.01.2021

*Corresponding author: Samiullah Allahbaksh Auti

\section{Abstract}

Shark liver oil is one of the sources of cellular energy and provides repair and restoration of damaged cells, and supports in protection of the body from the emergence of tumorous conditions. The Shark liver oil was tested orally at the dose of $1 \mathrm{gm} / \mathrm{kg} /$ oral body weight, on gastric ulceration experimentally induced by Ethanol. The parameters considered to assess the Mucoprotective activity were percentage of ulcer, ulcer index, percentage of inhibition, $\mathrm{pH}$, free acidity and total acidity, GSH, LPO and ALP. Pre treatment with the Shark liver oil resulted in significant decrease of the ulcerated area and reduced $\mathrm{pH}$, free acidity and total acidity.

Keywords: Shark liver oil, Mucoprotective activity, Percentage of ulcer, Ulcer Index, Percentage of inhibition, LPOLipid peroxidise, GSH-Reduced Glutathione and ALP- Alkaline Phosphates.

Copyright ( $) 2021$ The Author(s): This is an open-access article distributed under the terms of the Creative Commons Attribution 4.0 International License (CC BY-NC 4.0) which permits unrestricted use, distribution, and reproduction in any medium for non-commercial use provided the original author and source are credited.

\section{INTRODUCTION}

Ulcer is a break in the continuity of epithelial layer or mucus membrane due to various causes like physical/chemical injuries or trauma etc. Common causes for ulcer is imbalance between the offensive factor like gastric acid, pepsin and defensive factor like mucin secretion etc. Other causes for gastric ulcer includes Helicobacter pylori infection, local trauma, ischemia reflux of bile, drugs like non steroidal anti inflammatory agents, alcohol etc [1, 2]. Presently multimodel treatment for gastric acid includes the use of anti secretory drugs like $\mathrm{H} 2$ blockers (ranitidine, famotidine etc), M1 blockers (pirenzepine, telenzepine etc), proton pump inhibitors (omeprazole, lansoprazole etc), and antibacterial agents like metronidazole, amoxicillin etc. Gastric acid suppressant having prohealing effect would be an ideal agent for the treatment of gastric ulcer. Use of carbanoxolone sodium derived from plant with an attempt to promote the healing of gastric acid was not satisfactory. Search continued to find a gastroprotective agent with healing promoting property. Hence, it was necessary to find out a suitable agent for treatment of peptic ulcer in natural marine oil of Shark [3]. Shark liver oil is one of the source of high cellular energy. It provides repair and restoration of damaged cells, contributes in cholesterol reduction, helps in the treatment of skin diseases, promotes skin regeneration and supports in protection of the body from the emergence of tumorous conditions and the negative effects of radiotherapy or chemotherapy. It also enhances oxygen transport and is a powerful antioxidant that can scavenge free radicals from the body before they start their debilitating effects. Shark squalene is an amazing immune enhancer that helps the body protect against all three types of common offenders: bacterial, viral, and fungal infections [4]. Squalene (C30H50) is a polyunsaturated aliphatic hydrocarbon of low density found in large quantities in the liver oils of deep-sea sharks (Centrophorus Granulosus). Squalene and its constituent Squalane are used in the pharmaceutical, cosmetic, lubrication, electronic, textile, aromatic and rubber industries. Interest in their medical and dermatological significance intensified when squalene was found to be a precursor of cholesterol and possessed a possible anti carcinogenic effect. Shark liver oil is used in natural medicine as immunity stimulant, cardiovascular protector and anti aging agent. These properties were related with the high amounts of alkylglycerols which are known to possess healing properties. Shark squalene also possesses excellent antiinflammatory and peripheral antinociceptive effects that may contribute to its use in the treatment of arthritis and other inflammatory disorders [5]. Shark liver oil is promoted as dietary supplement used to boost the immune system, fight off infections, heal wounds and to treat cancer. It also possess cell protecting abilities.

Citation: S. A. Auti et al (2021). Mucoprotective Activity of Shark Liver Oil on Ethanol Induced Gastric Ulcer in Rats. Saudi J Med Pharm Sci, 26 7(1): 26-31. 
Compare to other fish oils, Shark liver oils contains high amount of alkoxyglycerols and squalaminne which promotes healing properties [6]. Because of their immune boosting effects they are also claimed to help against colds, flu, chronic infections, asthma, psoriasis, arthritis and AIDS. Most of the scientific studies with shark liver oil have focused on its possible benefits against cancer and infections. Therefore Shark liver oil has been used for over 40 years as both a therapeutic and preventive agent. Various plant extracts has been tested for finding a suitable gastroprotectives, other fish oils are found to produce significant anti-ulcer properties [7]. Here in our study we pay our attention to find out a suitable agent for treatment of peptic ulcer in natural marine Shark liver oil [8].

\section{Material ANd Methods Chemicals}

Chemicals and drugs Chemicals and drugs Sucralfate (gift sample) used as reference standard was obtained from Cipla Pharmaceuticals Ltd., Bangalore India. All other chemicals and reagents used in this study were of analytical grade. Shark liver oil used as the test drug at a dose $(1 \mathrm{gm} / \mathrm{kg}$ p.o) was procured from Coastal Exports Corporation. Mangalore, Karnataka, India.

\section{Experimental Animals}

Male Wistar rats, weighing 150-200 g were used for antiulcer activity. The rats were housed in polyacrylic cages and maintained at $27 \pm 2{ }^{\circ} \mathrm{C}, 45-60 \%$ $\mathrm{RH}$ and $12 \mathrm{~h}$ photo period. They were provided with a standard pellet diet (Gold Mohur food and feeds Ltd., Vikhroli (East), Mumbai) India and water ad libitum. The experiment was carried out according to Committee for the Purpose of Control and Supervision of Experiments on Animals (CPCSEA) (112/1999/CPCSEA) and the study was approved by Institutional Animal Ethical Committee. Wistar rats of weighing between 150-200gbody weights were divided into 4 groups and each group comprised of 6 animals $(n=6)$.

\section{Grouping}

Group 1: Normal Group 1:

Group 2: Control Group 2:

Group 3: Sucralfate-500 mg/kg, p.o.).
Group 4: Shark liver oil 1gm/kg p.o [9]

\section{MeTHODS}

Vehicle, standard drug and Shark squalene were administered by oral route, $30 \mathrm{~min}$ prior to the administration of $1 \mathrm{ml} / 200 \mathrm{gm}$ absolute ethanol to $18 \mathrm{~h}$ fasted animals. One hour after ethanol administration, the animal were sacrificed. The stomach was removed and the gastric contents were collected. The gastric juice was centrifuged at $3000 \mathrm{rpm}$ for min and gastric volume, $\mathrm{pH}$, free acidity and total acidity were estimated. The stomach was cut opened along the greater curvature and pinned on a soft board for evaluating ulcer index and mucus content of the stomach was determined The gastric juice was centrifuged at $3000 \mathrm{rpm}$ for $30 \mathrm{~min}$ and gastric volume, $\mathrm{pH}$, free acidity and total acidity were estimated. The stomach was cut opened along the greater curvature and pinned on a soft board for evaluating ulcer index and mucus content of the stomach was determined [10, 11]. $0=$ no ulcer, $1=$ superficial ulcer, $2=$ deep ulcer, $3=$ perforation. $\mathrm{UI}=\mathrm{UN}+\mathrm{US}+\mathrm{UP} \times 10-1$

UN -Average No. of ulcers per animal, US average of severity score, UP- $\%$ of ulcers with ulcer.

Inhibition $\%=[(\mathrm{UI}$ control $-\mathrm{UI}$ treated $) / \mathrm{UI}$ control $] \mathrm{x}$ 100

The isolated stomachs were kept in formalin solution $(15 \%)$ and then histopathological examination was done. Statistical analysis is expressed as Mean \pm SEM, followed by using one-way analysis of variance (ANOVA) followed by Dunnett's test. $\mathrm{p}<0.0001$ was considered statistically significant.

\section{RESULTS AND DISCUSSION}

Shark liver oil is rich in alkylglycerols, which are naturally found in mother's milk and in bone marrow. It also contains pristane, squalene, vitamins A, D, omega-3fatty acids, triglycerides, glycerol ethers, and fatty alcohols [12]. The present study summarizes the Mucoprotective property of Shark liver oil on Ethanol induced ulcer model in rats. In Ethanol induced ulcer model it significantly inhibits the ulcer index as compared to control. However in Ethanol induced ulcer model for Shark liver oil showed good ulcer protection.

Table-1: Mucoprotective activity of Shark liver oil in Ethanol induced ulcer model

\begin{tabular}{|c|c|c|c|}
\hline Sl. No & Treatment & Ulcer score $($ mean \pm SEM) & \% Ulcer protection \\
\hline 1 & Control & $4.91 \pm 1.7190$ & $0.00 \%$ \\
\hline 2 & Sucralfate & $1.0883 \pm 0.21033^{* * * *}$ & $77.93 \%$ \\
\hline 3 & Shark Squalene & $2.163 \pm 0.35866^{* * * *}$ & $55.87 \%$ \\
\hline
\end{tabular}

Data were expressed as the mean \pm S.E.M., $\mathrm{n}=6$ in each group.

One way ANOVA Dunnett's t test: $* * * \mathrm{P}<0.0001 * \mathrm{P}<0.05$

After administration of ethanol (1 $\mathrm{ml}$ intragastrically) ulcers were formed in stomach .It is evident from the above table that the ulcer area in control, Sucralfate and Shark Squalene is 4.91 \pm 1.7190 , $1.0883 \pm 0.21033,2.163 \pm 0.35866$ respectively which is significant ( $\mathrm{p}$ value $<0.0001$ ). The \% Ulcer protection of 
S. A. Auti et al., Saudi J Med Pharm Sci, Jan, 2021; 7(1): 26-31

Shark Squalene was $55.87 \%$ and that of Sucralfate was $77.93 \%$.

LPO level of Shark Squalene, Sucralfate and Control found to be $1.455 \pm 0.04817,1.225 \pm 0.04863$, and $2.161 \pm 0.04801$ respectively. The ALP readings of Shark Squalene, Sucralfate and Control observed to be $66.16 \pm 1.0863,76.50 \pm 2.18707$, and 104.5 \pm 1.2583 respectively. The Glutathione level of Shark Squalene, Sucralfate and Control is reported to be 118.74 \pm 3.3217 ,
$118.74 \pm 3.3217$ and $76.025 \pm 2.9380$ respectively. All the above results are statistically significant.

Histopathological investigation has revealed that extent of edema, congestion, hemorrhage and necrosis are similar in case of sucralfate and Shark Squalene treated but much less than that of control groups. Sucralfate and Shark Squalene treated showed mild damage where as control group showed severe damage, as observed in Table-2.

Table-2: Mucoprotective activity of Shark squalene when compared with Sucralfate

\begin{tabular}{|c|c|c|c|c|c|}
\hline $\begin{array}{c}\text { Sl. } \\
\text { No }\end{array}$ & Treatment & $\begin{array}{c}\text { Volume of gastric juice in } \\
\text { ml }\end{array}$ & $\mathbf{p H}$ & $\begin{array}{c}\text { Free acidity } \\
\text { meq///100g }\end{array}$ & $\begin{array}{c}\text { Total acidity } \\
\text { meq///100g }\end{array}$ \\
\hline 1 & Control & $2.36 \pm 0.08031$ & $1.80 \pm 0.09717$ & $73.83 \pm 2.1203$ & $155.33 \pm 5.3082$ \\
\hline 2 & Sucralfate & $1.71 \pm 0.13970^{* * * *}$ & $3.45 \pm 0.3225^{* * * *}$ & $57.6 \pm 2.2461^{* * * *}$ & $119.5 \pm 3.374^{* * * *}$ \\
\hline 3 & $\begin{array}{c}\text { Shark } \\
\text { squalene }\end{array}$ & $1.633 \pm 0.10601^{* * * *}$ & $2.58 \pm 0.06418^{* * * *}$ & $63.5 \pm 1.1180^{* * * *}$ & $132.6 \pm 3.6571^{* * * *}$ \\
\hline
\end{tabular}

Data were expressed as the mean \pm S.E.M., $\mathrm{n}=6$ in each group.

One way ANOVA Dunnett's t test: *** $\mathrm{P}<0.0001 * \mathrm{P}<0.05$

Table-3: Comparative study of reduced glutathione, lipid peroxidase and alkaline phosphatase of Shark squalene treated with Sucralfate treated rats (ANOVA)

\begin{tabular}{|c|c|c|c|c|c|}
\hline $\begin{array}{c}\text { Sl. } \\
\text { no }\end{array}$ & Treatment & Mucin content & $\begin{array}{c}\text { Glutathione }(\boldsymbol{\mu M} / \mathbf{g} \text { of } \\
\text { wet gland }\end{array}$ & $\begin{array}{c}\text { Malondialdehyde }(\boldsymbol{\mu M} \\
\text { MDA }) / \mathbf{g} \text { wet gland }\end{array}$ & ALP (IU) \\
\hline 1 & Control & $0.1508 \pm 0.00648$ & $76.025 \pm 2.9380$ & $2.161 \pm 0.04801$ & $104.5 \pm 1.2583$ \\
\hline 2 & Sucralfate & $0.343 \pm 0.01693^{* * * *}$ & $119.68 \pm 3.4033^{* * * *}$ & $1.225 \pm 0.04863^{* * * *}$ & $76.50 \pm 2.18707^{* * * *}$ \\
\hline 3 & $\begin{array}{c}\text { Shark } \\
\text { Squalene }\end{array}$ & $0.301 \pm 0.01225^{* * *}$ & $118.74 \pm 3.3217^{* * * *}$ & $1.455 \pm 0.04817^{* * * *}$ & $66.16 \pm 1.0863^{* * * *}$ \\
\hline
\end{tabular}

Data were expressed as the mean \pm S.E.M., $\mathrm{n}=6$ in each group.

One way ANOVA Dunnett's t test: $* * * \mathrm{P}<0.0001 * \mathrm{P}<0.05$

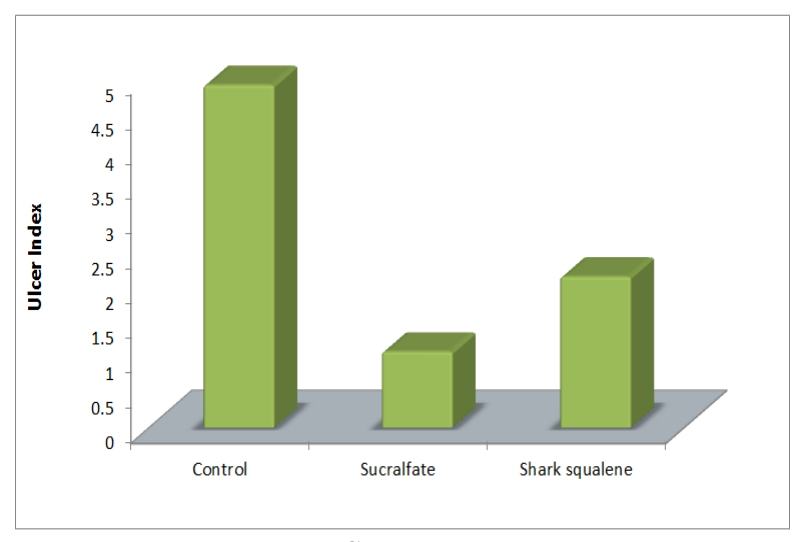

ULCER INDEX

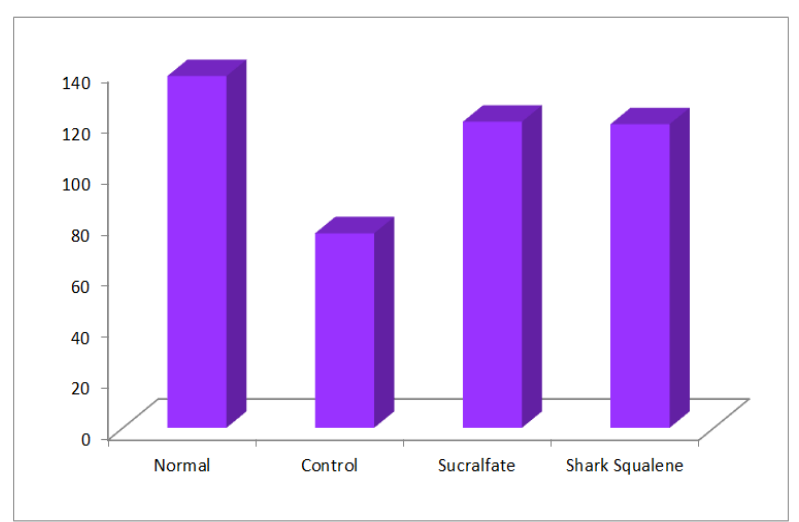

GSH-Reduced Glutathione $(\mu \mathrm{M} / \mathrm{g}$ of wet gland)

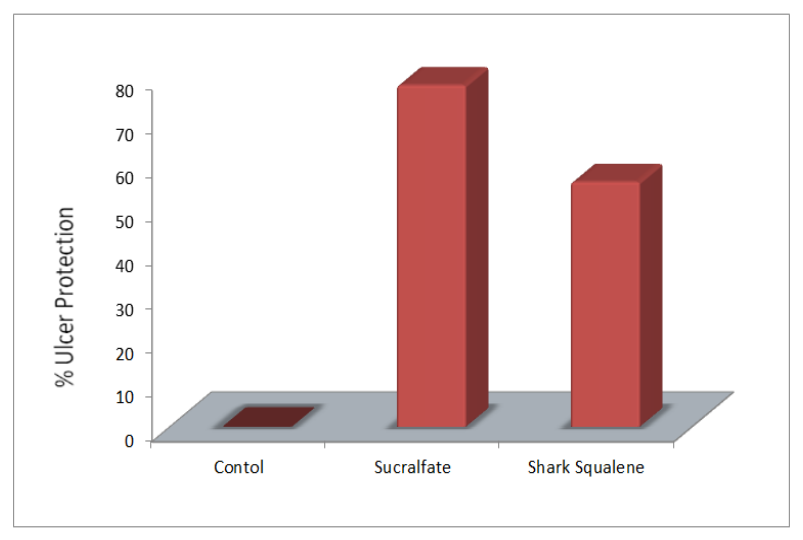

\% PERCENTAGE ULCER PROTECTIONS

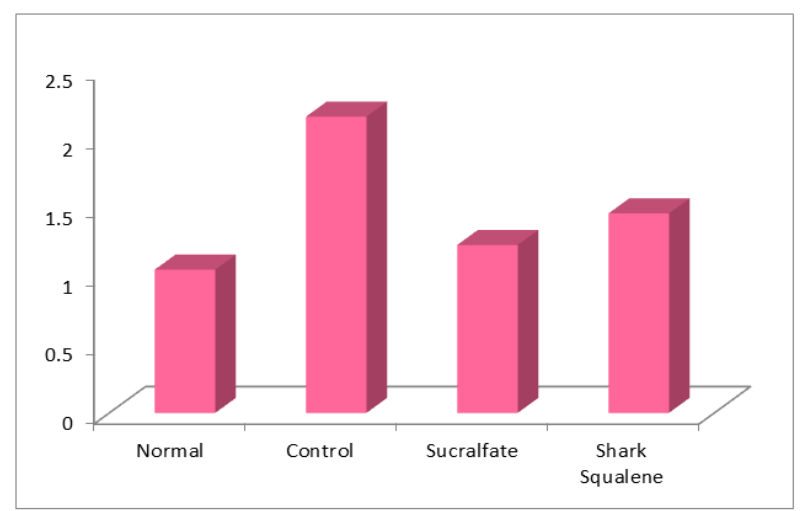

LPO-Lipid peroxidise ( $\mu \mathrm{M} / \mathrm{g}$ wet gland) 
S. A. Auti et al., Saudi J Med Pharm Sci, Jan, 2021; 7(1): 26-31

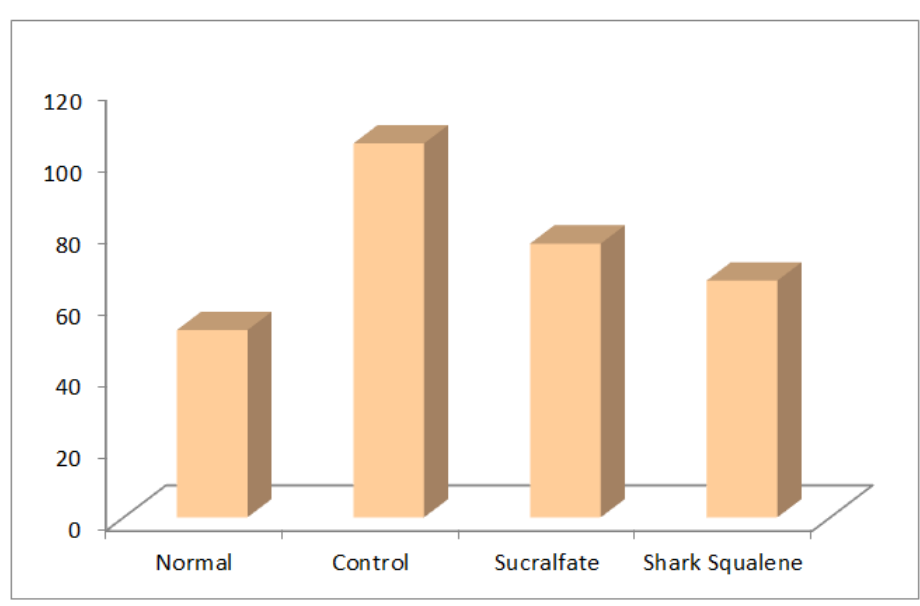

ALP-Alkaline phosphatase (IU)
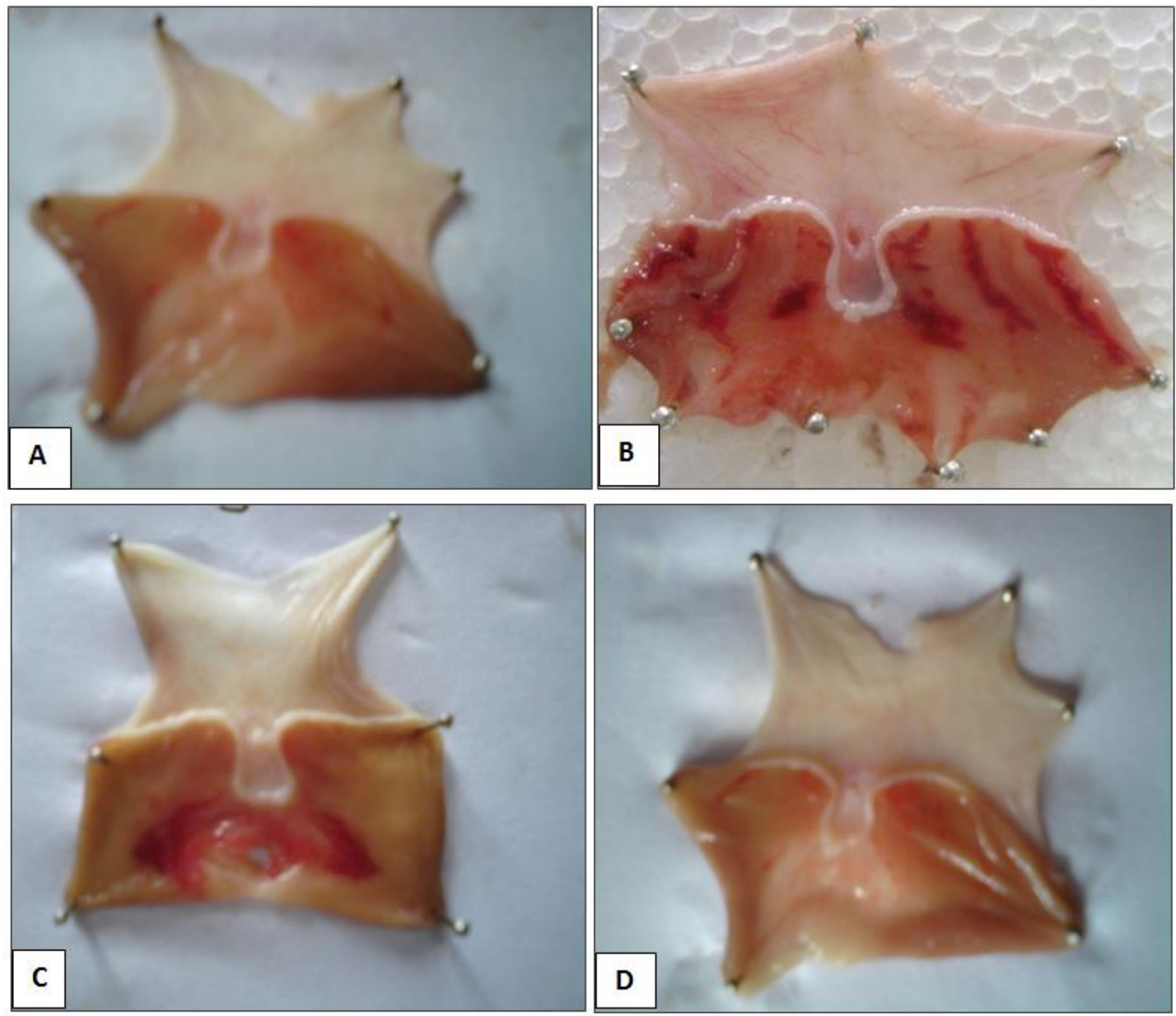

Fig-1: Photographs of rat stomachs in Ethanol induced ulcer mode: A) NORMAL; B) CONTROL; C) SHARK SQUALENE (Test); D) SUCRALFATE (Standard) 


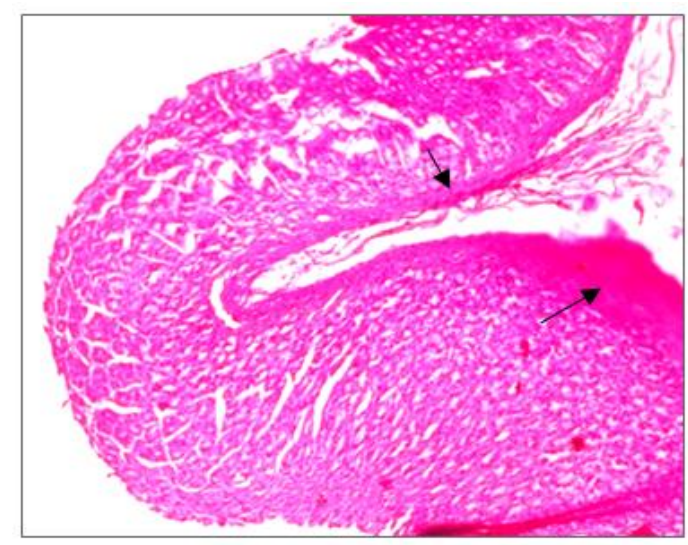

NORMAL

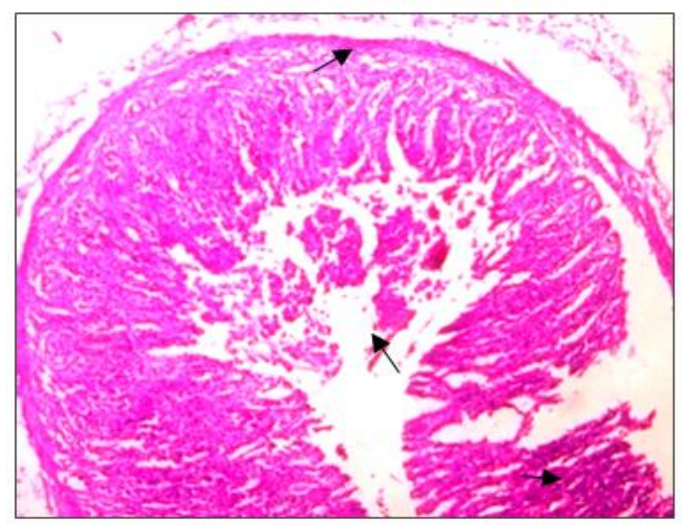

SHARK SQUALENE

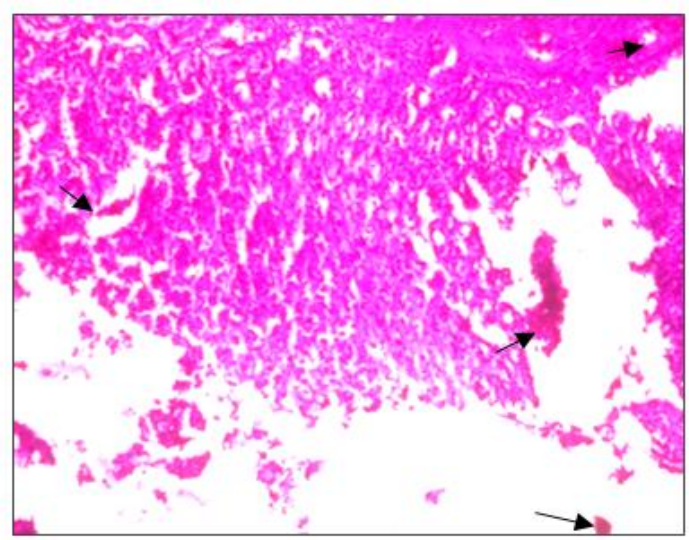

CONTROL

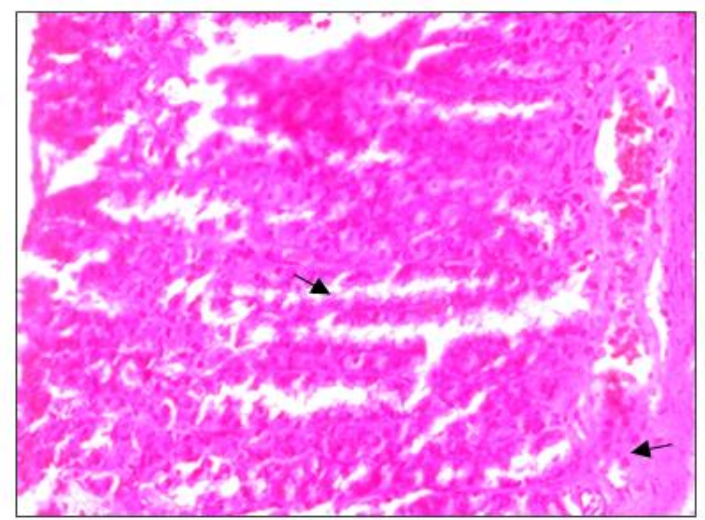

SUCRALFATE

Fig-2: Histopathological investigation of the stomachs of rats in Ethanol induced ulcer model (Microscopic appearance)

\section{Normal}

Gastric section of normal rats showing normal mucosa and sub-mucosa.

\section{Control}

Gastric section of untreated rats showing ulceration of the mucosal cells associated with mixed inflammatory changes and necrosis intervening these epithelial cells are seen aggregates of macrophages and neutrophil infiltration in the gastric mucosa and submucosa shows severe edema.

\section{Shark Squalene}

Gastric section of Shark liver oil treated group showing scattered neutrophils, lymphocytes and mild submucosal edema. Also seen are some regenerated epithelial cells.

\section{Sucralfate}

Gastric section of Sucaralfate group showing gastric mucosa with intact epithelium, lamina propria and muscularis mucosa intervening the epithelial cells are seen scattered mononuclear inflammatory cells and few congested vascular spaces and submucosa shows moderate edema.

\section{DisCUSSION}

There are several factors that may known to induce ulcer in human beings, such as; stress, chronic use of anti-inflammatory drugs and continuous use of alcohol. Although in most cases the etiology of ulcer is totally unknown and it is accepted that it is a result of an imbalance between aggressive factors and maintenance of the mucosal integrity through the endogenous defence mechanism. The present study reveals that Shark Squalene treated groups showed a significant increase in gastric $\mathrm{pH}$, reduces the gastric volume, free acidity and total acidity when compared to control. Ethanol produces mucosal damage by severe gastric hemorrhagic erosions. The genesis of ethanolinduced gastric lesion is multifactorial with the depletion of gastric or mucus content as one of the involved factors and this damage induced by ethanol may be due to mucosal leukotriene release. Mucosal blood flow has also been attributed to be an important factor in the damage caused by alcohol and is modulated by PG. Submucosal venular constriction by ethanol and eventual injury is caused due to perturbation of superficial mucosal cells. Ethanolinduced damage to the gastric mucosa is associated with a significant production of free radicals leading to an increased lipid peroxidation and damage to the cell and cell membranes. The candidate for an effective drug against peptic ulcer should basically act either by 
S. A. Auti et al., Saudi J Med Pharm Sci, Jan, 2021; 7(1): 26-31

reducing the aggressive factors on gastrointestinal mucosa or by increasing mucosal resistance against them [13]. Result of the present study indicates that Shark liver oil has significant beneficial effects in Ethanol induced mucosal damage in rat model. Therefore, the presence of alkoxyglycerols content and other bioactive compounds in Shark liver oil may be mostly associated with the gastroprotective effect [14]. Also the antioxidant and antimicrobial property as reported of Shark liver oil could be one of the possible mechanisms for Mucoprotective action [15]. However other mechanisms of action might be involved in gastroprotective action. Further studies are required to explore the gastroprotective action.

\section{CONCLUSION}

From the above study it's concluded that in Ethanol induced ulcer model Shark Squalene showed promising cytoprotective properties due to decrease in Lipid peroxidase. ALP and increased in reduced Glutathione. The cytoprotective activity was supported by Histopathological studies.

\section{ACKNOWLEDGEMENT}

The Authors are thankful to Dr. V.H. KULKARNI, Principal- SETS college of pharmacy, Dharwad, Karnataka state. India for providing necessary facilities and for his support to carry out this Research Project. We are also thankful to M/s Nissar. F.M, Coastal Exports Corporation, Mangalore for providing Shark Liver Oil as gift sample.

\section{REFERENCES}

1. Umamaheswari, M., Asokkumar, K., Rathidevi, R., Sivashanmugam, A. T., Subhadradevi, V., \& Ravi, T. K. (2007). Antiulcer and in vitro antioxidant activities of Jasminum grandiflorum L. Journal of ethnopharmacology, 110(3), 464470.

2. Bodhankar, S. L., \& Vyawahare, N. S. (2005). A textbook of Pathophysiology, 2nd ed. Pune, Nirali prakashan, 6:1-6.

3. http://www.vitadigest.com Shark squalene (shark liver oil) from Vita Digest, Walnut CA 91789 [online] (2009).

4. Shark oil monograph from Natural medicines comprehensive data base. Scientific Gold
Standard for Evidence-Based clinical information on natural medicines. Therapeutic research faculty, Stockton: CA 95208; Nov 20, (2009).

5. http//:www.pdrhealth.com/drug_info/nmdrugsprfil es/nutsupdrugs/squ_0240.shtm

6. Solomon, N., Passwater, R., \& Joelsson, I. (1997). Shark liver oil: Nature's amazing healer. Kensington Books.

7. Biological actions and Clinical applications of Shark liver oil. Pol Merkur Lekarskj-2006 [PUBMED].

8. Riber, C., Wøjdemann, M., Bisgaard, T., Ingels, H., Rehfeld, J. F., \& Olsen, O. (1999). Fish oil reduces gastric acid secretion. Scandinavian journal of gastroenterology, 34(9), 845-848.

9. Al-Meshal, M. A., Lutfi, K. M., \& Tariq, M. (1991). Cod liver oil inhibits indomethacin induced gastropathy without affecting its bioavailability and pharmacological activity. Life sciences, 48(14), 1401-1409.

10. Mohammed, A., Mohammed, A., \& Prasad, V. S. (2009). Antiulcer activity of Allium sativum bulb juice in rats. Saudi Pharmaceutical Journal, 17(1), 70-77.

11. Al-Harbi, M. M., Islam, M. W., Al-Shabanah, O. A., \& Al-Gharably, N. M. (1995). Effect of acute administration of fish oil (omega-3 marine triglyceride) on gastric ulceration and secretion induced by various ulcerogenic and necrotizing agents in rats. Food and chemical toxicology, 33(7), 553-558.

12. Vogel, H. G., Vogel, W. H., Scholkens, B. A., Sandow, J., \& Vogel, W. F. (2002). Drug Discovery and Evaluation of Pharmacological Assays, 2nd Ed, New York, Springer-Verlag Berlin Heidelberg, 870.

13. Gajjar, I. M. (1946). Chemical composition of shark liver oil, J Sci Ind Res. 5:18.

14. Akutsu, K., Tanaka, Y., \& Hayakawa, K. (2006). Occurrence of polybrominated diphenyl ethers and polychlorinated biphenyls in shark liver oil supplements. Food additives and contaminants, 23(12), 1323-1329.

15. Pugliese, P. T., Jordan, K., Cederberg, H., \& Brohult, J. (1998). Some biological actions of alkylglycerols from shark liver oil. The Journal of Alternative and Complementary Medicine, 4(1), 87-99. 